

\title{
Synthesis, Spectroscopic, Antibacterial and Antioxidant Activities of Pd(Ii) Mixed-Ligand Complexes Containing Tridentate Schiff Bases
}

\author{
A.I. Demehin ${ }^{1,2}$, M. A. Oladipo ${ }^{2^{*}}$ and B. Semire ${ }^{2}$ \\ ${ }^{1}$ Department of Chemistry, Adeyemi College of Education, Ondo, Nigeria. \\ ${ }^{2}$ Ladoke Akintola University of Technology, Department of Pure and Applied Chemistry, \\ Ogbomoso, Nigeria.
}

\begin{abstract}
Dd(II) complexes of the form [PdLNH3] (where L = N-salicylidene-o-aminophenol (L1), 1 N-(5-methoxysalicylidene-o-aminophenol) (L2) and N-(2-hydroxy-1-naphthalidene)-oaminophenol) (L3) containing ammonia and ONO tridentate Schiff bases were synthesized. These complexes were characterized by elemental analysis, infrared, ultraviolet-visible, proton and carbon-13 spectroscopies. The NMR spectra showed that the Schiff bases coordinated to the palladium(II) ion through the two deprotonated phenolic oxygen and azomethine nitrogen atoms. The presence of ammonia molecules in these complexes were indicated by the IR and $1 \mathrm{H}$ NMR spectra. The spectral data suggested a square planar geometry for the complexes. The biological studies revealed that the complexes displayed better antibacterial and antioxidant activities than the parent Schiff bases.
\end{abstract}

Keywords: Schiff base, complex, Palladium(II) ion, antibacterial, antioxidant

\section{Introductio}

Schiff bases are compounds with an imine or azomethine, $(\mathrm{HC}=\mathrm{N})$ group [1]. They function as excellent chelating ligands with wide range of properties tunable by introduction of substituents with different electron-donating or electronwithdrawing groups on either the carbonyl or amine ring. Intra- and intermolecular hydrogen bonds can be formed from Schiff bases obtained from various substituted salicylaldehydes and 2-hydroxyl-1-naphthaldehyde and these usually determine their chemical and physicochemical properties. The resultant imines are involved in binding with metal ions via nitrogen lone pair electrons. Schiff bases have played essential roles in understanding the coordination chemistry of transition metal ions. The azomethine moiety is significant for biological activities, it is a very useful active centre of many biological systems [2, 3]. Studies showed that Schiff bases derived from salicylaldehyde, 2-hydroxyl-1-naphthaldehyde including their derivatives and their complexes with some transition metals displayed significant biological properties because of the presence of nitrogen and oxygen atoms which are active donor atoms in the molecules of these compounds. These biological properties make Schiff bases and the complexes gain attention, some of the reported properties are antimicrobial, analgesic, antioxidants, antimalarial, anticonvulsant and anti-inflammatory [3-8].

Many complexes have been synthesized for their pronounced biological activities. There are many studies on Pd(II) complexes with Schiff

"Corresponding author e-mail address: moolapipupo@lautech.edu.ng, ${ }^{*}$ Telephone: +2348169846400

Received 26/4/2019; Accepted 27/6/2019

DOI: $10.21608 /$ ejchem.2019.12319.1766

(C)2019 National Information and Documentation Center (NIDOC) 
base ligands because they play important roles in bioinorganic chemistry and redox enzyme systems. They can act as catalyst and provide the basis of models for active sites of biological systems [3]. However, literature search showed that reports on complexes bearing ammonia are extremely limited. Hence this study, the synthesis, spectroscopic, antibacterial and antioxidant activities of $\mathrm{Pd}(\mathrm{II})$ complexes of tridentate Schiff bases.

\section{Experimental}

\section{Materials}

Salicylaldehyde, 5-methoxysalicylaldehyde, 2-hydroxy-1-naphthaldehyde, 2-aminophenol, palladium(II) acetate, ammonium hydroxide and formic acid were purchased from Merck (Germany) which were used as supplied. The solvents were of pure grade except ethanol and water that were distilled.

\section{Instruments}

A Thermo Finnigan Flash EA 1112 Series was used for the elemental analyses $(\mathrm{C}, \mathrm{H}, \mathrm{N})$. The Infrared spectroscopy analyses were carried out using the attenuated (ATR) technique with a Perkin-Elmer 400 FT-IR/FT-FIR spectrometer. A MPD Mitamura Riken Kogyo (Japan) electrothermal was used to determine the melting points. The nuclear magnetic resonance spectra were carried out on a Bruker Avance III 600 Spectrometer in solution with DMSO- $\mathrm{d}_{6}$ and tetramethylsilane (TMS) as internal standard at $600 \mathrm{MHz}$. The UV-Visible were recorded in $1.0 \mathrm{x}$ $10^{-4}$ M DMSO solution using Shimadzu UV 1800 Spectrophotometer on 250-900 nm.

\section{Synthesis}

The Schiff bases syntheses

$5.0 \mathrm{mmol}$ of the 2-aminophenol in $10 \mathrm{ml}$ of ethanol was added in drops to $5.0 \mathrm{mmol}$ of the corresponding salicylaldehyde in $20 \mathrm{ml}$ of the same solvent. The resulting solution was stirred for 2 hours on addition of three drops of formic acid. The coloured solids precipitated were separated by filtration and recrystallized from hot ethanol.

$$
\mathrm{L}_{1}: \mathrm{R}_{1}=\mathrm{H} ; \quad \mathrm{L}_{2}: \mathrm{R}_{1}=\mathrm{OCH}_{3}, \mathrm{~L}_{3}: \mathrm{R}_{1}=\mathrm{C}_{4} \mathrm{H}_{4}
$$<smiles>[R]c1ccc(O)c(/C=N/c2ccccc2O)c1</smiles>

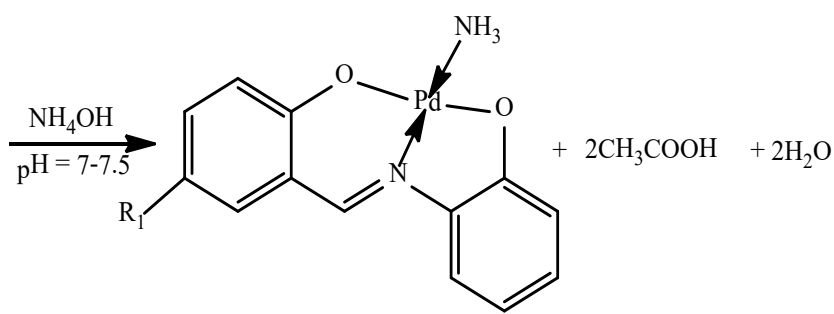

\section{Scheme 1. Synthetic route of the Schiff base ligands.}

Synthesis of the Pd(II) complexes

A methanolic solution of $\mathrm{Pd}\left(\mathrm{CH}_{3} \mathrm{COO}\right)_{2}(5.0$ $\mathrm{mmol})$ was added in drops to the corresponding Schiff base solution $(5.0 \mathrm{mmol})$ while stirring in 10 $\mathrm{ml}$ of the same solvent. Some drops of ammonia hydroxide were added to modify the $\mathrm{pH}$ of the resulting mixture to 7-7.5 and refluxed at $60{ }^{\circ} \mathrm{C}$ for 4 hours. The coloured solids precipitated were filtered by vacuum filtration, washed with distilled water, diethyl ether and methanol. These were dried over silica gel in a desiccator for two days and recrystallized from DMSO.

Antibacterial study

The antibacterial potentials of the compounds were measured against some Gram-positive and Gram-negative bacterial strains by agarwell diffusion method. The Gram-positive bacterial strains were Streptococcus agalactiae and Staphylococcus aureus while Escherichia coli, Klebsiella pneumonia, Proteus mirabilis, Pseudomonas aeruginosa and Salmonella<smiles>[R]c1ccc(O)c(C=Nc2ccccc2O)c1</smiles>

Scheme 2. Synthetic route of the Pd(II) complexes. 
typhimurium were the Gram-negative bacterial strains used. The Nutrient agar medium was used to sub-culture the isolates of bacterial strains which were nurtured at $37{ }^{\circ} \mathrm{C}$ for 24 hours. 20 $\mathrm{ml}$ of disinfected Nutrient agar medium was dispensed in each germfree Petri dish after modifying the bacterial strains cultures to 0.5 McFarland standard, these were allowed to gel. The dishes were swabbed with the inocula of the bacterial strains and left for 15 minutes to adsorb unto the gel. Varying concentrations of the samples $(5 \mathrm{mg} / \mathrm{ml}, 10 \mathrm{mg} / \mathrm{ml}, 15 \mathrm{mg} / \mathrm{ml})$ were filled into the wells that were drilled on the seeded agar dishes by a sterile cork borer of 6 $\mathrm{mm}$ diameter. These were kept for 1 hour in the refrigerator to allow for thorough circulation of the samples into the medium and then nurtured for 24 hours at $37{ }^{\circ} \mathrm{C}$ before observing the inhibition zones. Antimicrobial activities were expressed as inhibition diameter zones in millimeter ( $\mathrm{mm})$. Standard Gentamycin $(10 \mu \mathrm{g} / \mathrm{ml})$ was employed as control [9-11].

\section{Phosphomolybdate Total Antioxidant Capacity (PTAC) Assay}

The total antioxidant capacities (TAC) of the compounds were determined by phosphomolybdenum assay and ascorbic acid was used as the standard. $1.0 \mathrm{ml}$ of reagent $(0.6$ $\mathrm{M}$ sulphuric acid, $28 \mu \mathrm{M}$ sodium phosphate and
$4 \mu \mathrm{M}$ ammonium molybdate) was reacted with a fractional part of the extract solution $(1.0 \mathrm{ml}$ of $1000 \mu \mathrm{g})$. The covered tubes were incubated at 95 ${ }^{\circ} \mathrm{C}$ in a water bath for 90 minutes after which the samples were cooled to room temperature and a UV spectrophotometer was used to measure the absorbance of the aqueous solution of each at 695 $\mathrm{nm}$. The procedure was repeated for an empty solution containing $1.0 \mathrm{ml}$ of reagent solution. The TAC studies were expressed as equivalents of ascorbic acid [12].

\section{Results and Discussion}

The physicochemical data of the synthesized Schiff bases and the complexes are presented in Table 1. The Schiff base ligands and the complexes were stable and coloured solids. The complexes were not soluble in water and almost all organic solvents except in DMSO and DMF. The complexes have higher melting points than the parent Schiff base ligands, this showed that they have better stability than the Schiff bases. The elemental analysis data confirmed the formation of 1:1:1 [Palladium: Schiff base: ammonia] molar ratio. The crystals obtained in DMSO were not suitable for X-ray diffraction measurement. No crystal was obtained in DMF. Attempts to isolate single crystal suitable for X-ray diffraction measurement were not successful.

TABLE 1. The physicochemical data of the Schiff bases and the Pd(II) complexes.

\begin{tabular}{|c|c|c|c|c|c|c|c|c|}
\hline \multirow[t]{2}{*}{ Compounds } & \multirow[t]{2}{*}{ Molecular formula } & \multirow[t]{2}{*}{$\begin{array}{r}\text { Molecular } \\
\text { weight }\end{array}$} & \multirow[t]{2}{*}{ Colours } & \multirow[t]{2}{*}{$\begin{array}{r}\text { Melting } \\
\text { points }\left({ }^{\circ} \mathrm{C}\right)\end{array}$} & \multirow[t]{2}{*}{$\%$ Yield } & & \multicolumn{2}{|c|}{$\begin{array}{r}\text { Elemental analysis (\%) } \\
\text { Found (Calculated) }\end{array}$} \\
\hline & & & & & & & $\mathrm{C}$ & $\mathrm{H}$ \\
\hline $\mathrm{L}_{1}$ & $\mathrm{C}_{13} \mathrm{H}_{11} \mathrm{NO}_{2}$ & 213.14 & Orange & 187 & 97 & $\begin{array}{r}73.25 \\
(73.23)\end{array}$ & $5.21(5.20)$ & $\begin{array}{r}6.60 \\
(6.57)\end{array}$ \\
\hline $\mathrm{PdL}_{1} \mathrm{NH}_{3}$ & $\mathrm{C}_{13} \mathrm{H}_{12} \mathrm{~N}_{2} \mathrm{O}_{2} \mathrm{Pd}$ & 334.67 & Orange & $>260$ & 75 & $\begin{array}{c}46.69 \\
(46.66)\end{array}$ & $3.64(3.61)$ & $\begin{array}{l}8.38 \\
(8.37)\end{array}$ \\
\hline $\mathrm{L}_{2}$ & $\mathrm{C}_{14} \mathrm{H}_{13} \mathrm{NO}_{3}$ & 243.14 & Wine & 157 & 95 & $\begin{array}{r}69.10 \\
(69.12)\end{array}$ & $5.38(5.39)$ & $\begin{array}{r}5.77 \\
(5.76)\end{array}$ \\
\hline $\mathrm{PdL}_{2} \mathrm{NH}_{3}$ & $\mathrm{C}_{14} \mathrm{H}_{14} \mathrm{~N}_{2} \mathrm{O}_{3} \mathrm{Pd}$ & 364.69 & Orange & $>260$ & 72 & $\begin{array}{c}46.13 \\
(46.11)\end{array}$ & $3.88(3.87)$ & $\begin{array}{l}7.69 \\
(7.68)\end{array}$ \\
\hline $\mathrm{L}_{3}$ & $\mathrm{C}_{17} \mathrm{H}_{13} \mathrm{NO}_{2}$ & 263.29 & Yellow & 249 & 86 & $\begin{array}{r}77.56 \\
(77.55)\end{array}$ & $\begin{array}{r}5.00 \\
(4.98)\end{array}$ & $\begin{array}{r}5.29 \\
(5.32)\end{array}$ \\
\hline $\mathrm{PdL}_{3} \mathrm{NH}_{3}$ & $\mathrm{C}_{17} \mathrm{H}_{14} \mathrm{~N}_{2} \mathrm{O}_{2} \mathrm{Pd}$ & 384.73 & Brown & $>260$ & 82 & $\begin{array}{l}53.08 \\
(53.07)\end{array}$ & $\begin{array}{l}3.66 \\
(3.67)\end{array}$ & $\begin{array}{l}7.27 \\
(7.28)\end{array}$ \\
\hline
\end{tabular}




\section{Spectroscopic studies}

FT-IR spectra

The IR spectral data of the compounds are presented in Table 2. The free Schiff base $\left(\mathrm{L}_{1}, \mathrm{~L}_{2}\right.$ and $\left.\mathrm{L}_{3}\right)$ spectra showed the azomethine, $\mathrm{r}(-\mathrm{HC}=\mathrm{N})$ vibrational frequencies at 1627,1617 and $1626 \mathrm{~cm}^{-1}$ respectively, these wave numbers shifted backward (1604-1597 $\mathrm{cm}^{-1}$ ) in the Pd(II) complexes (Figs. 1-3). This revealed the involvement of the azomethine nitrogen atoms in coordination with the $\mathrm{Pd}(\mathrm{II})$ ions and the palladium-ligand bonds formation. Absorption bands at 1274, 1228 and $1247 \mathrm{~cm}^{-1}$ in the free Schiff bases spectra were attributed to the phenolic $\mathrm{C}-\mathrm{O}$ stretching vibrations of $\mathrm{L}_{1}, \mathrm{~L}_{2}$ and $\mathrm{L}_{3}$ respectively. These bands shifted to higher wave numbers at $1306-1261 \mathrm{~cm}^{-1}$ in the $\mathrm{Pd}(\mathrm{II})$ complexes, these showed the involvement of the oxygen atoms of the phenolic groups in coordination with the $\mathrm{Pd}(\mathrm{II})$ ion. The free Schiff bases $\left(\mathrm{L}_{1}, \mathrm{~L}_{2}\right.$ and $\left.\mathrm{L}_{3}\right)$ exhibited hydroxyl $\mathrm{r}(\mathrm{O}-\mathrm{H})$ vibrational frequencies at 3746 , 3747 and 3119-2427 $\mathrm{cm}^{-1}$ respectively, these were absent in the complexes which further confirmed the removal of the phenolic groups protons and the attachment of oxygen to the $\mathrm{Pd}(\mathrm{II})$ ion $[3,13]$. The complexes showed new absorption bands at 3353,3340 and $3332 \mathrm{~cm}^{-1}$ respectively assigned to $\mathrm{r}(\mathrm{N}-\mathrm{H})$ stretching vibrations of ammonia ($\mathrm{NH}_{3}$ ) groups, these indicated the presence of $-\mathrm{NH}_{3}$ groups in the complexes and showed the attachment of the nitrogen atoms of the $-\mathrm{NH}_{3}$ groups to the $\mathrm{Pd}(\mathrm{II})$ ion [14]. The bands around $489-471 \mathrm{~cm}^{-1}$ and $544-508 \mathrm{~cm}^{-1}$ were attributed to the stretching vibrations of the palladiumoxygen, $\mathrm{r}(\mathrm{Pd}-\mathrm{O})$ and palladium-nitrogen, $\mathrm{r}(\mathrm{Pd}-\mathrm{N})$ bands respectively. These confirmed the attachment of the Schiff bases to the Pd(II) ion via the oxygen and nitrogen atoms of the phenolic and azomethine groups respectively $[3,9,13,15]$.

Table 2. The IR data of the Schiff bases and the Pd(II) complexes.

\begin{tabular}{|c|c|c|c|c|c|c|c|}
\hline \multirow{2}{*}{\multicolumn{2}{|c|}{ Schiff bases/Complexes }} & \multirow[b]{2}{*}{$\mathrm{v}(\mathrm{O}-\mathrm{H})$} & \multirow[b]{2}{*}{$\mathrm{r}(\mathrm{N}-\mathrm{H})$} & \multirow[b]{2}{*}{$\mathrm{v}(\mathrm{C}=\mathrm{N})$} & \multirow[b]{2}{*}{$\mathrm{r}(\mathrm{C}-\mathrm{O})$} & \multicolumn{2}{|c|}{ IR bands $\left(\mathrm{cm}^{-1}\right)$} \\
\hline & & & & & & $\mathrm{r}(\mathrm{M}-\mathrm{O})$ & $\mathrm{r}(\mathrm{M}-\mathrm{N}$ \\
\hline \multirow[t]{5}{*}{$\mathrm{L}_{1}$} & & 3746 & - & 1627 & 1274 & - & - \\
\hline & $\mathrm{PdL}_{1} \mathrm{NH}_{3}$ & - & 3332 & 1597 & 1306 & 489 & 525 \\
\hline & $\mathrm{L}_{2}$ & 3747 & - & 1626 & 1247 & - & - \\
\hline & $\mathrm{PdL}_{2} \mathrm{NH}_{3}$ & - & 3353 & 1604 & 1304 & 488 & 544 \\
\hline & $\mathrm{L}_{3}$ & $3119-2427$ & - & 1617 & 1228 & - & - \\
\hline $\mathrm{PdNAPNH}_{3}$ & & - & 3340 & 1600 & 1261 & 471 & 508 \\
\hline
\end{tabular}






A

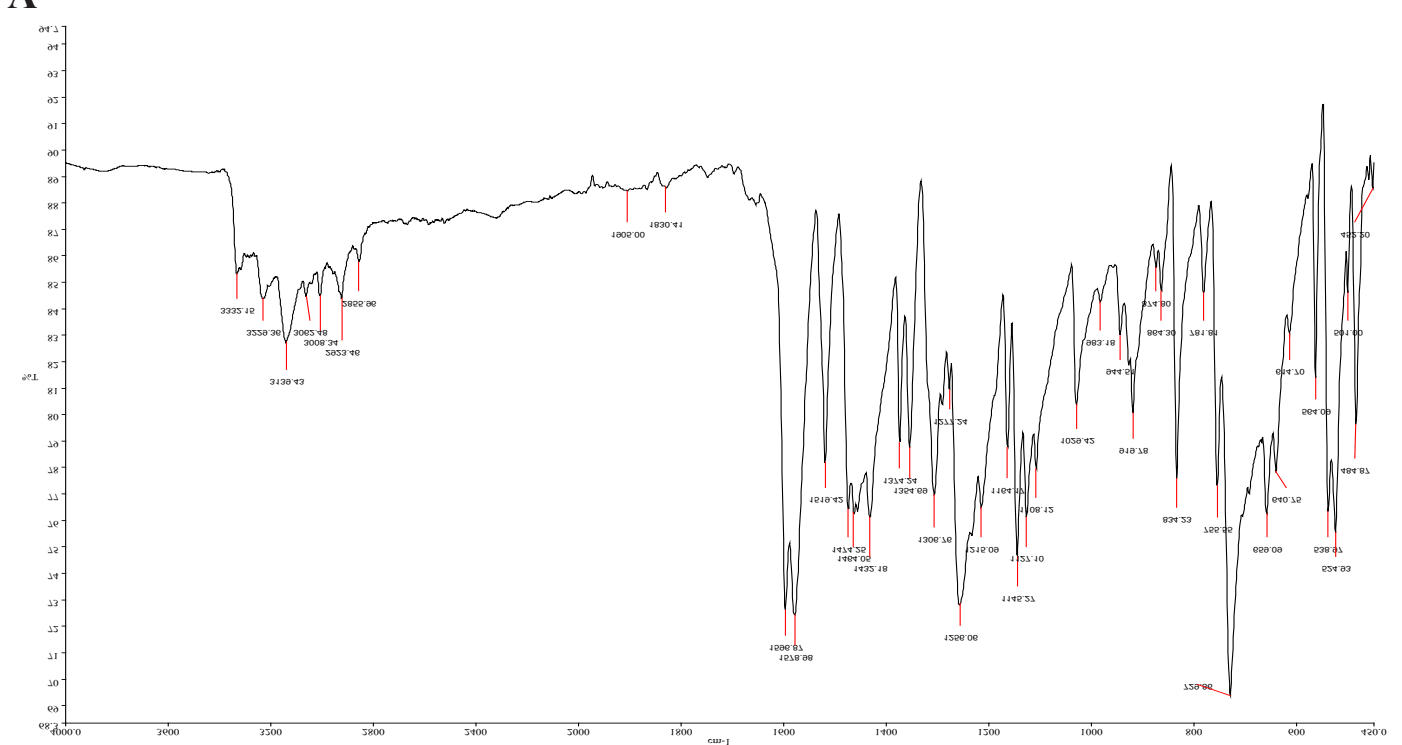

B

Fig. 1. IR spectra of $\mathrm{L}_{1}(\mathrm{~A})$ and $\mathrm{PdL}_{1} \mathrm{NH}_{3}(\mathrm{~B})$. 



Fig. 2. IR spectra of $\mathrm{L}_{2}(\mathrm{~A})$ and $\mathrm{PdL}_{2} \mathrm{NH}_{3}(\mathrm{~B})$.


Fig. 3. IR spectra of L3 (A) and PdL3NH3 (B).

Egypt.J.Chem. Vol. 62, Special Issue (Part 2) (2019) 


\section{NMR spectra}

The NMR data $\left({ }^{1} \mathrm{H}\right.$ and $\left.{ }^{13} \mathrm{C}\right)$ of the compounds are presented in Table 3. The free Schiff bases displayed two singlet signals for the two phenolic $-\mathrm{OH}$ protons at $\delta 13.78-13.07 \mathrm{ppm}$ and $\delta 10.31-9.68 \mathrm{ppm}$. The spectra showed singlet signals at $\delta 8.92 \mathrm{ppm}\left(\mathrm{L}_{1}\right)$, $8.89 \mathrm{ppm}\left(\mathrm{L}_{2}\right)$ and $9.47 \mathrm{ppm}\left(\mathrm{L}_{3}\right)$ attributed to the azomethine $(-\mathrm{HC}=\mathrm{N})$ protons. The protons of the aromatic rings appeared as multiplets around $\delta$ 8.34-6.70 ppm [4, 16, 17]. The three protons of the methoxy $\left(-\mathrm{OCH}_{3}\right)$ groups in ' $\mathrm{L}_{2}$ ' appeared as a sharp singlet signal at $\delta 3.71 \mathrm{ppm}[18,19]$. A comparison of the ${ }^{1} \mathrm{H}$ NMR spectra of the parent Schiff bases with the Pd(II) complexes spectra (Figs. 4-6) revealed that the two phenolic $-\mathrm{OH}$ protons in the parent Schiff bases were not present in the $\mathrm{Pd}(\mathrm{II})$ complexes. This indicated the detachment of the Schiff bases $-\mathrm{OH}$ protons before coordinating with the $\mathrm{Pd}(\mathrm{II})$ ion. It also corroborated the coordination of oxygen atoms to $\mathrm{Pd}(\mathrm{II})$ ion. Moreover, the coordination of the azomethine nitrogen atoms of the parent Schiff bases to the $\mathrm{Pd}(\mathrm{II})$ ion were indicated by the displacements of the chemical shifts of the azomethine hydrogen to upfield region at $\delta 9.42-8.75 \mathrm{ppm}$. The aromatic protons appeared as multiplets around $\delta$ 8.57-6.53 ppm for the complexes [4, 17]. The new singlet signals at $\delta 3.56 \mathrm{ppm}, \delta 3.51 \mathrm{ppm}$ and $\delta 3.50 \mathrm{ppm}$ in the $\mathrm{Pd}(\mathrm{II})$ complexes were assigned to the three hydrogen atoms of $-\mathrm{NH}_{3}$ groups [14]. The three $\mathrm{OCH}_{3}$ group protons of ' $\mathrm{L}_{2}$ ' in the $\mathrm{Pd}$ (II) complexes appeared as a sharp singlet signal at $\delta 3.70 \mathrm{ppm}[18$, 20]. Signals at $3.33 \mathrm{ppm}$ and $2.45-2.50 \mathrm{ppm}$ are for $\mathrm{H}_{2} \mathrm{O} / \mathrm{DMSO}$ and DMSO respectively in all the spectra.

$\mathrm{s}=$ singlet, $\mathrm{m}=$ multiplets, $\mathrm{Ar}=$ aromatic.

The ${ }^{13} \mathrm{C}$ NMR spectra of the palladium(II) complexes are consistent with the proton NMR of the complexes. The ${ }^{13} \mathrm{C}$ NMR spectrum of $\mathrm{PdL}_{1} \mathrm{NH}_{3}$ (Fig. 7) showed a peak at $\delta 167.47 \mathrm{ppm}$ which confirmed the presence of azomethine carbon in the complex. The aromatic carbons' peaks appeared in the range $\delta 162.98-114.79 \mathrm{ppm}$ [17]. In $\mathrm{PdL}_{2} \mathrm{NH}_{3}{ }^{13} \mathrm{C}$ NMR spectrum (Fig. 8), the azomethine carbon appeared at $\delta 167.39 \mathrm{ppm}$ and the aromatic carbons' peaks appeared in the range $\delta$ 156.49-114.79 ppm while the carbon peak for $-\mathrm{OCH}_{3}$ group appeared at $\delta 55.96 \mathrm{ppm}[18,19]$. $\mathrm{PdL}_{3} \mathrm{NH}_{3}{ }^{13} \mathrm{C}$ NMR spectrum (Fig. 9) showed the azomethine carbon's peak at $\delta 167.18 \mathrm{ppm}$ and the aromatic carbons' peaks in the range $\delta 163.60$ 111.71 ppm [9].

Table 3. The ${ }^{1} \mathrm{H}$ and ${ }^{13} \mathrm{C}$ NMR spectra data of the Schiff bases and Pd(II) complexes.

\begin{tabular}{llc}
\hline Schiff Bases and Complexes & \multicolumn{2}{c}{ Assignment } \\
\hline $\mathrm{L}_{1}$ & $\delta(\mathrm{ppm})$ & ${ }^{1} \mathrm{H}$ NMR \\
& 13.78 & $(\mathrm{~s}, 1 \mathrm{H},-\mathrm{OH})$ \\
& 9.73 & $(\mathrm{~s}, 1 \mathrm{H},-\mathrm{OH})$ \\
& 8.92 & $(\mathrm{~s}, 1 \mathrm{H},-\mathrm{HC}=\mathrm{N})$ \\
& $7.56-6.84$ & $\left(\mathrm{~m}, 8 \mathrm{H}, \mathrm{CH}_{\mathrm{Ar}}\right)$ \\
$\mathrm{PdL}_{1} \mathrm{NH}_{3}$ & - & - \\
& - & - \\
& 8.75 & $\left(\mathrm{~s}, 1 \mathrm{H},-\mathrm{HC}^{2}\right)$ \\
& $7.90-6.50$ & $(\mathrm{~m}, 8 \mathrm{H}, \mathrm{CH})$ \\
& 3.51 & $\left(\mathrm{~s}, 3 \mathrm{H},-\mathrm{NH}_{3}\right)$ \\
& $162.98-114.79$ & $\left(12 \mathrm{C}, \mathrm{C}_{\mathrm{Ar}}\right)$ \\
& 167.47 & $(1 \mathrm{C}, \mathrm{HC}=\mathrm{N})$ \\
\hline
\end{tabular}




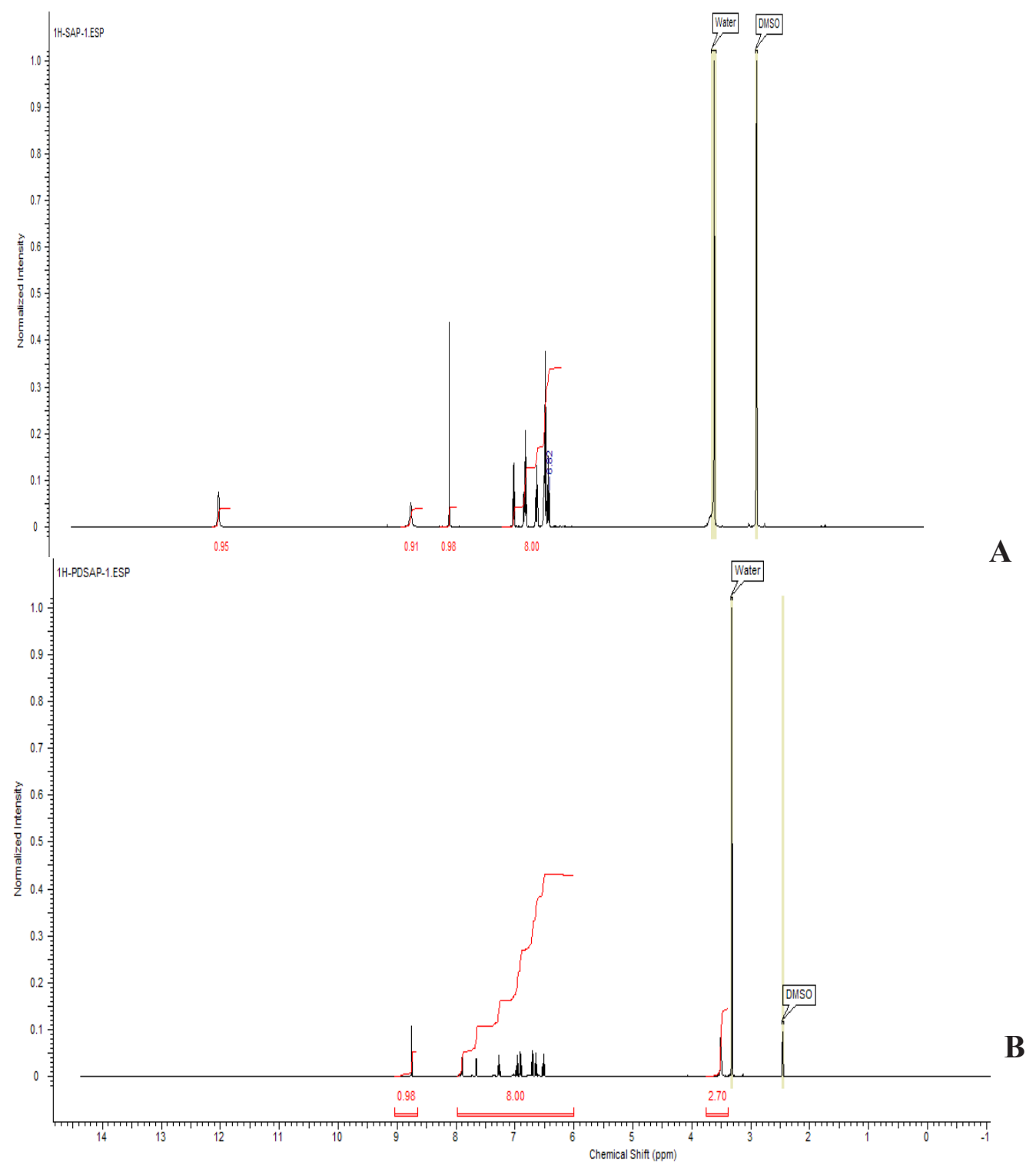

Fig. 4. ${ }^{1} \mathrm{H}$ NMR spectra of $\mathrm{L}_{1}(\mathrm{~A})$ and $\mathrm{PdL}_{1} \mathrm{NH}_{3}(\mathrm{~B})$. 


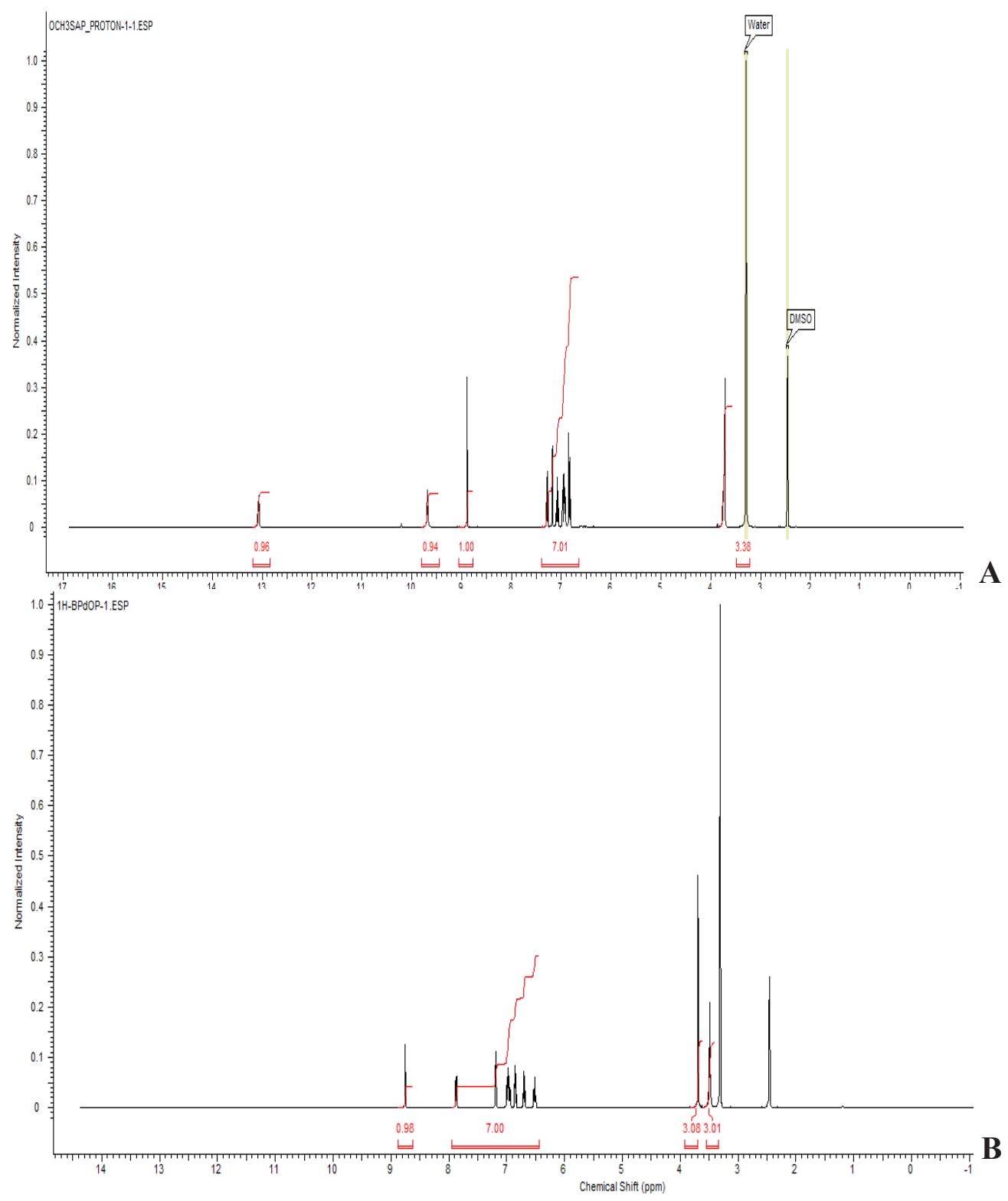

Fig. 5. ${ }^{1} \mathrm{H}$ NMR spectra of $\mathrm{L}_{2}(\mathrm{~A})$ and $\mathrm{PdL}_{2} \mathrm{NH}_{3}(\mathrm{~B})$. 



Fig. 6. ${ }^{1} \mathrm{H} N M R$ spectra of $\mathrm{L}_{3}(\mathrm{~A})$ and $\mathrm{PdL}_{3} \mathrm{NH}_{3}(\mathrm{~B})$.



Fig. 7. ${ }^{13} \mathrm{C}$ NMR of $\mathrm{PdL}_{1} \mathrm{NH}_{3}$ complex.

Egypt.J.Chem. Vol. 62, Special Issue (Part 2) (2019) 




Fig. 8: ${ }^{13} \mathrm{C}$ NMR of $\mathrm{PdL}_{2} \mathrm{NH}_{3}$ complex.

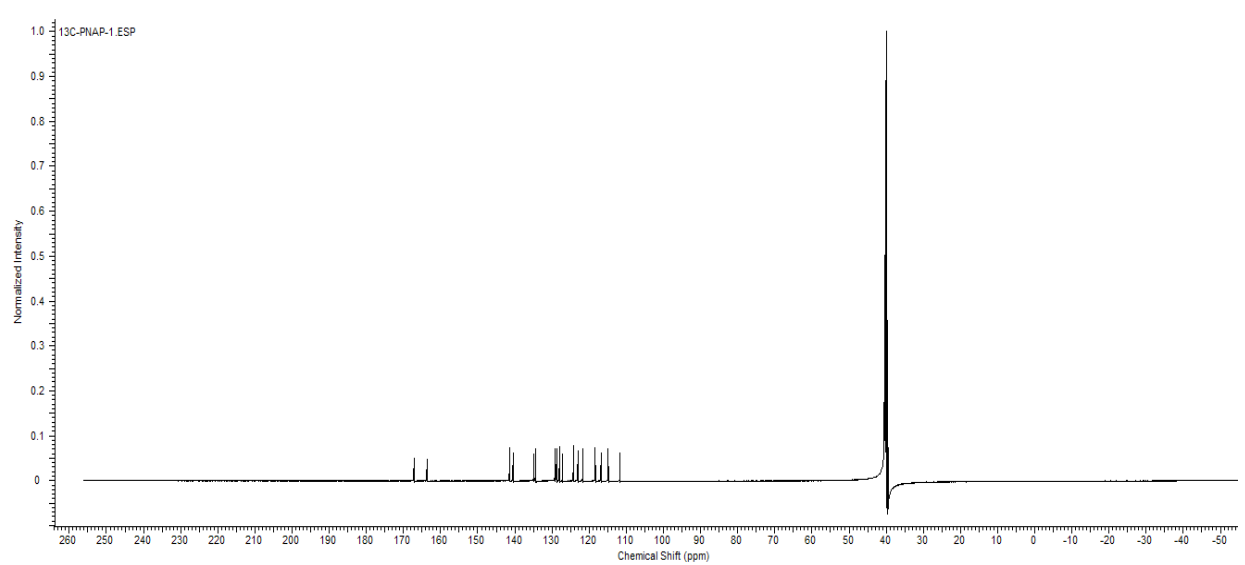

Fig.9. ${ }^{13} \mathrm{C}$ NMR of $\mathrm{PdL}_{3} \mathrm{NH}_{3}$ complex.

\section{UV-Visible spectra}

The UV-Visible spectral data of the compounds are presented in Table 4. The parent Schiff bases spectra showed two absorption bands around $37027.04-36625.03 \mathrm{~cm}^{-1}$ and 28328.61-22271.71 $\mathrm{cm}^{-1}$ which were attributed to $\pi \rightarrow \pi^{*}$ and $\mathrm{n} \rightarrow \pi^{*}$ transitions respectively $[9,18,20]$. These moved to lower frequencies in the complexes spectra corroborating the attachment of the Schiff base ligands to the $\mathrm{Pd}(\mathrm{II})$ ions. $\mathrm{PdL}_{1} \mathrm{NH}_{3}$ displayed three bands at $32467.53 \mathrm{~cm}^{-1}, 23752.97 \mathrm{~cm}^{-1}$ and $22624.43 \mathrm{~cm}^{-1}$ attributed to $\pi \rightarrow \pi^{*},{ }^{1} \mathrm{~A}_{1 \mathrm{~g}} \rightarrow{ }^{1} \mathrm{E}_{1 \mathrm{~g}}$ and ${ }^{1} \mathrm{~A}_{1 \mathrm{~g}} \rightarrow{ }^{1} \mathrm{~B}_{1 \mathrm{~g}}$ transitions respectively [17]. $\mathrm{PdL}_{2} \mathrm{NH}_{3}$ spectrum displayed two absorptions at 32154.34 $\mathrm{cm}^{-1}$ and $21551.72 \mathrm{~cm}^{-1}$ assigned to $\pi \rightarrow \pi^{*}$ and ${ }^{1} \mathrm{~A}_{1 \mathrm{~g}} \rightarrow{ }^{1} \mathrm{~B}_{1 \mathrm{~g}}$ transitions respectively [19]. $\mathrm{PdL}_{3} \mathrm{NH}_{3}$ spectrum revealed three absorptions at 31152.65 , 22471.91 and $21186.44 \mathrm{~cm}^{-1}$ assigned to $\pi \rightarrow \pi^{*}$, ${ }^{1} \mathrm{~A}_{1 \mathrm{~g}} \rightarrow{ }^{1} \mathrm{E}_{\mathrm{lg}}$ and ${ }^{1} \mathrm{~A}_{1 \mathrm{~g}} \rightarrow{ }^{1} \mathrm{~B}_{1 \mathrm{~g}}$ respectively. The UVVisible spectra data revealed that all the complexes displayed absorption bands above $16666.67 \mathrm{~cm}^{-1}$ (below $600 \mathrm{~nm}$ ). The absence of absorption band below $16666.67 \mathrm{~cm}^{-1}$ (above $600 \mathrm{~nm}$ ) revealed a large crystal-field splitting which is characteristic of square planar geometry [16]. Therefore, a square planar geometry was proposed for the $\mathrm{Pd}(\mathrm{II})$ complexes. Furthermore, the complexes displayed sharp signals in their proton NMR spectra which is also characteristics of square planar geometry [21], thereby corroborating the proposed square planar geometry for the complexes.

Egypt.J.Chem. Vol. 62, Special Issue (Part 2) (2019) 
Table 4. Electronic spectral data of the salicylaldimines and the Pd(II) complexes.

\begin{tabular}{lll}
\hline Compounds & Bands in $\mathrm{cm}^{-1}$ & Assignments \\
\hline $\mathrm{L}_{1}$ & $36625.03,28328.61$ & $\pi \rightarrow \pi^{*}, \mathrm{n} \rightarrow \pi^{*}$ \\
$\mathrm{PdL}_{1} \mathrm{NH}_{3}$ & $32467.53,23752.97,22624.43$ & $\pi \rightarrow \pi^{*},{ }^{1} \mathrm{~A}_{1 \mathrm{~g}} \rightarrow{ }^{1} \mathrm{E}_{1 \mathrm{~g}},{ }^{1} \mathrm{~A}_{1 \mathrm{~g}} \rightarrow{ }^{1} \mathrm{~B}_{1 \mathrm{~g}}$ \\
$\mathrm{~L}_{2}$ & $37027.04,27027.03$ & $\pi \rightarrow \pi^{*}, \mathrm{n} \rightarrow \pi^{*}$ \\
$\mathrm{PdL}_{2} \mathrm{NH}_{3}$ & $32154.34,21154.34$ & $\pi \rightarrow \pi^{*},{ }^{1} \mathrm{~A}_{1 \mathrm{~g}} \rightarrow{ }^{1} \mathrm{~B}_{1 \mathrm{~g}}$ \\
$\mathrm{~L}_{3}$ & $30769.23,26859.00$ & $\pi \rightarrow \pi^{*}, \mathrm{n} \rightarrow \pi^{*}$ \\
$\mathrm{PdL}_{3} \mathrm{NH}_{3}$ & $31152.65,22471.91,21186.44$ & $\pi \rightarrow \pi^{*},{ }^{1} \mathrm{~A}_{1 \mathrm{~g}} \rightarrow{ }^{1} \mathrm{E}_{1 \mathrm{~g}},{ }^{1} \mathrm{~A}_{1 \mathrm{~g}} \rightarrow{ }^{1} \mathrm{~B}_{1 \mathrm{~g}}$ \\
\hline
\end{tabular}

Antibacterial activities

The antibacterial activities results of the compounds are summarized in Table 5. The results revealed that all the synthesized Schiff base ligands and the Pd(II) complexes exhibited antibacterial activities. The $\mathrm{Pd}(\mathrm{II})$ complexes displayed better inhibitory effects against the bacterial strains than the parent Schiff bases. This showed that the antibacterial activities of the parent Schiff bases increase on coordination with the $\mathrm{Pd}(\mathrm{II})$ ion. This can be related to chelation theory and probably the synergistic effect of ammonia molecules in the complexes. On chelation, ligands become more potent, consequently destroying or restricting the growth of more bacterial strains than the free ligands. Chelation reduces the polarity of the metal ion thereby easing the inflow of the complexes across the bacteria's cell wall $[5,18,20,22,23]$.

In comparison with standard Gentamycin, $\mathrm{PdL}_{2} \mathrm{NH}_{3}$ exhibited more inhibitory effects against the bacterial strains than standard Gentamycin. Moreover, all the complexes showed more potent activities against $S$. agalactiae than standard Gentamycin which was inactive against it. The methoxy-substituted $\mathrm{Pd}(\mathrm{II})$ complex $\left(\mathrm{PdL}_{2} \mathrm{NH}_{3}\right)$ exhibited the most potent activity among the complexes.

\section{Total antioxidant capacity}

The TAC results of the compounds are presented in Table 6 . The results revealed that the PdII) complexes exhibited higher TAC than the Schiff base ligands, this could be related to the coordination of the $\mathrm{Pd}(\mathrm{II})$ ions and probably the synergistic effect of ammonia molecules in the complexes. The bonding of the central metal ion to the ligands facilitates their abilities to make unpaired electrons stable, thereby help remove free radicals $[17,24]$. Hence, making the complexes better antioxidants than the parent ligands. $\mathrm{PdL}_{2} \mathrm{NH}_{3}$ exhibited the highest TAC among the $\mathrm{Pd}(\mathrm{II})$ complexes.

Egypt.J.Chem. Vol. 62, Special Issue (Part 2) (2019)

\begin{tabular}{|c|c|c|c|c|c|c|c|c|}
\hline$\cong \stackrel{\infty}{g}$ & \pm & \pm & $\approx$ & $\underset{\sim}{\sim}$ & $\underline{9}$ & $\stackrel{0}{-}$ & ' & ิ \\
\hline 음 & \pm & \pm & 2 & $\stackrel{\sim}{\sim}$ & $\simeq$ & $\stackrel{0}{0}$ & ' & \\
\hline$\cap \stackrel{b}{g}$ & \pm & $\Xi$ & $\approx$ & $\stackrel{\infty}{\sim}$ & $\simeq$ & $\stackrel{0}{-}$ & ' & \\
\hline$\simeq \stackrel{b}{g}$ & $\stackrel{\circ}{\sim}$ & $\infty$ & $\stackrel{\infty}{-}$ & $\stackrel{i}{ }$ & $=$ & $\infty$ & ' & $\beth$ \\
\hline$\stackrel{\infty}{g}$ & $\stackrel{\circ}{-}$ & $\infty$ & $\stackrel{\infty}{\sim}$ & iิ & $=$ & $\stackrel{\infty}{\sim}$ & ' & \\
\hline$n \stackrel{b 0}{g}$ & $\cong$ & 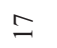 & $\infty$ & $\stackrel{\sim}{\sim}$ & $=$ & $\stackrel{\infty}{-}$ & ' & \\
\hline$\cong \stackrel{\infty}{\Xi}$ & $I$ & 9 & ஓి & $\tilde{n}$ & $=$ & $\stackrel{\infty}{\sim}$ & ' & ㄱ. \\
\hline$\stackrel{\infty}{g}$ & $\stackrel{0}{-}$ & $\stackrel{2}{2}$ & in & $\tilde{n}$ &  & $\stackrel{0}{-}$ & ' & \\
\hline i $\stackrel{50}{\Xi}$ & $\stackrel{\bullet}{-}$ & 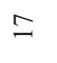 & ஜ & $\tilde{n}$ & $\cong$ & $\stackrel{0}{-}$ & ' & \\
\hline$\simeq \stackrel{b 0}{g}$ & \pm & $\approx$ & $\approx$ & $\ddot{n}$ & $\simeq$ & \pm & ' & ' \\
\hline 음 & \pm & $\stackrel{\sim}{\sim}$ & $\approx$ & 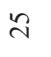 & 은 & $\simeq$ & ' & \\
\hline 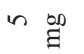 & $\Xi$ & ㄱ. &  & $\stackrel{\sim}{\sim}$ & & $\simeq$ & ' & \\
\hline$\simeq \stackrel{\infty 0}{\Xi}$ & 2 & $\stackrel{n}{\sim}$ & 尺 & $\approx$ & \pm & $=$ & ' & 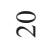 \\
\hline$\stackrel{\circ}{=}$ & $=$ & $\stackrel{\infty}{-}$ & 尺े & $\approx$ & \pm & $=$ & ' & \\
\hline$\backsim \stackrel{g}{\Xi}$ & $=$ & $\stackrel{\infty}{\sim}$ & ஓ & ल & \pm & $=$ & ' & \\
\hline$\simeq \stackrel{\circ}{\Xi}$ & $\stackrel{\bullet}{\circ}$ & $=$ & ి & $\stackrel{さ}{\sim}$ & $\Xi$ & $\stackrel{0}{-}$ & ' & $\stackrel{\infty}{-}$ \\
\hline 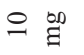 & $\stackrel{0}{-}$ & $=$ & $\stackrel{\sim}{ }$ & $\stackrel{\sim}{\sim}$ & \pm & $\stackrel{0}{\circ}$ & ' & \\
\hline 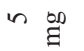 & $\cong$ & $\stackrel{0}{\sim}$ & 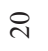 & $\approx$ & $\Xi$ & $\stackrel{0}{-}$ & ' & \\
\hline$\simeq \stackrel{b 0}{\Xi}$ & $=$ & ปี & $\approx$ & $\stackrel{\sim}{N}$ & $\stackrel{\infty}{=}$ & 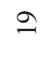 & ' & ㄱ. \\
\hline$\stackrel{\circ}{=}$ & $\stackrel{\circ}{-}$ & $\stackrel{\infty}{\sim}$ & $\approx$ & $\stackrel{ \pm}{d}$ & \pm & $\stackrel{0}{-}$ & ' & \\
\hline$\backsim \stackrel{g}{ }$ & $\stackrel{0}{-}$ & $\stackrel{\infty}{\infty}$ & $\approx$ & $\stackrel{\Xi}{\sim}$ & \pm & $\stackrel{0}{-}$ & ' & \\
\hline$\exists$ & 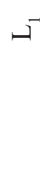 & $\begin{array}{l}\bar{z}^{\infty} \\
\bar{z} \\
\bar{z}\end{array}$ & $\Omega^{2}$ & $\begin{array}{l}\mathbb{Z}_{n}^{m} \\
\tilde{z}^{n}\end{array}$ & $u^{m}$ & $\begin{array}{l}\bar{z}_{m}^{m} \\
\bar{z}\end{array}$ &  & \\
\hline
\end{tabular}


Table 6. Total antioxidant capacities of the Schiff bases and the Pd(II) complexes.

\begin{tabular}{|c|c|c|}
\hline & Schiff bases/Complexes & TAC $\mu$ g per mg AA \\
\hline $\mathrm{L}_{1}$ & & 0.68 \\
\hline $\mathrm{PdL}_{1} \mathrm{NH}_{3}$ & & 0.72 \\
\hline $\mathrm{L}_{2}$ & & 0.78 \\
\hline $\mathrm{PdL}_{2} \mathrm{NH}_{3}$ & & 1.41 \\
\hline $\mathrm{L}_{3}$ & & 0.62 \\
\hline $\mathrm{PdL}_{3} \mathrm{NH}_{3}$ & & 0.77 \\
\hline
\end{tabular}

\section{Conclusion}

$\mathrm{Pd}(\mathrm{II}) \quad$ complexes containing ammonia, $\mathrm{N}$-(salicylidene)-o-aminophenol, $\quad \mathrm{N}-(5-$ methoxysalicylidene)-o-aminophenol and $\mathrm{N}-(2-$ hydroxy-1-naphthalidene)-o-aminophenol were synthesized. They were characterized by different spectroscopic methods which confirmed their formation. A square planar geometry was suggested for the complexes. The antibacterial activities of the complexes follow the order: $\mathrm{PdL}_{2} \mathrm{NH}_{3}>\mathrm{PdL}_{1} \mathrm{NH}_{3}>$ $\mathrm{PdL}_{3} \mathrm{NH}_{3}$ while the TAC follow the order $\mathrm{PdL}_{2} \mathrm{NH}_{3}>$ $\mathrm{PdL}_{3} \mathrm{NH}_{3}>\mathrm{PdL}_{1} \mathrm{NH}_{3}$.

\section{Acknowledgement}

Demehin, A.I. appreciates the Organization of Women in Science in Developing World (OWSD), Trieste, Italy for the research fellowship granted to her to study in the Department of Chemistry, University of Malaya, Kuala Lumpur, Malaysia. She is grateful to Prof. Hapipah, M. A. Department Of Chemistry, University of Malaya for allowing the use of her laboratory for the research and providing for the analyses. Also, she acknowledges the management of Adeyemi College of Education, Ondo, Nigeria for granting her a study leave.

\section{References}

1. Kalaivani S., Priya N.P., Arumachalam S., Schiff bases : facile synthesis, spectral characterization and biocidal studies. International Journal of Applied Biology and Pharmaceutical Technology, 3, 219-223(2012).

2. Schilf W., Kamienski B., Szady-Chełmieniecka A., Kołodzie B.J, Grech E., Zarzeczanska D., Wcisło A., Ossowski T., Structure investigation of intramolecular hydrogen bond in some substituted salicylaldehydes and 4-aminoantipyrine derivatives in solution and in the solid state. Spectrochimica Acta Part A: Molecular and Biomolecular Spectroscopy, 109, 47-54(2013).

3. Kundu S., Pramanik A.K., Mondal A.S., Mondal
T.K., Ni(II) and $\mathrm{Pd}(\mathrm{II})$ complexes with new N,O donor thiophene appended Schiff base ligand: Synthesis, electrochemistry, X-ray structure and DFT calculation. Journal of Molecular Structure, 1116, 1-8(2016).

4. Saha S., Jana S., Gupta S., Ghosh A., Nayek H.P., Syntheses, structures and biological activities of square planar $\mathrm{Ni}(\mathrm{II}), \mathrm{Cu}(\mathrm{II})$ complexes. Polyhedron, 107, 183-189(2016).

5. Ghosh A.K., Mitra M., Fathima A., Yadav H., Choudhury A.R., Nair B.U., Ghosh R., Antibacterial and catecholase activities of Co(III) and Ni(II) Schiff base complexes. Polyhedron, 107, $1-8(2016)$.

6. Chandra S., Vandana, Synthesis, spectroscopic, anticancer, and antibacterial studies of $\mathrm{Ni}(\mathrm{II})$ and $\mathrm{Cu}(\mathrm{II})$ complex with 2-carboxybenzalaldehyde thiosemicarbazone. Spectrochimica Acta Part A: Molecular Biomolecular Spectroscopy, 129, 333338(2014).

7. Refat M.S., El-Sayed M.Y., Adam A.M.A., Structural, Electronic and Thermal Studies of ChargeTransfer Complexes from the Schiff Base; N,N'-Disalicylidene-1,2-Phenylenediamine with Chloranilic Acid, p-Chloranil, TCNQ and DDQ. Canadian Chemical Transactions, 2, 149-159 (2014).

8. Yousif E., Majeed A., Al-Sammarrae K., Salih N., Salimon J., Abdullah B., Metal complexes of Schiff base: Preparation, characterization and antibacterial activity. Arabian Journal of Chemistry, 10, S1639S1644(2017).

9. Kiran T., Prasanth V.G., Balamurali M.M., Vasavi C.S., Munusami P., Sathiyanarayanan K.I., Pathak M., Synthesis, spectroscopic characterization and in vitro studies of new heteroleptic copper (II) complexes derived from 2-hydroxy napthaldehyde Schiff's bases and N, N donor ligands: Antimicrobial, DNA binding and cytotoxic investigations. Inorganica Chimica Acta, 433, 2634 (2015).

Egypt.J.Chem. Vol. 62, Special Issue (Part 2) (2019) 
10. Ali H.A., Fares H., Darawsheh M., Rappocciolo E., Akkawi M., Jaber S., Synthesis, characterization and biological activity of new mixed ligand complexes of $\mathrm{Zn}$ (II) naproxen with nitrogen based ligands. European journal of Medicinal Chemistry, 89, 67-76(2015).

11. Ololade Z.S., Olawore N.O., Olasoji S.O., Anosike S.O., Chemical Composition and Bactericidal Activities of the Leaf Essential Oil of Eucalyptus maculata Hook. Natural Products Chemistry \& Research, 5, 257(2017).

12. Pierre B.K., Pierre S.H., Tatjana S., Study of Polyphenol Content and Antioxidant Capacity of Myrianthus Arboreus (Cecropiaceae) Root Bark Extracts. Antioxidants, 4, 410-426(2015).

13. Biswas S., Pramanik A.K., Mondal T.K., Palladium(II) complex with thiazole containing tridentate ONN donor ligand: Synthesis, X-ray structure and DFT computation. Jounal of Molecular Structure, 1088 28-33(2015).

14. Belal A.A.M., El-Deen I.M., Farid N.Y., Rosan Z., Refat M.S., Synthesis, spectroscopic, coordination and biological activities of some transition metal complexes containing ONO tridentate Schiff base ligand. Spectrochimica Acta Part A: Molecular and Biomolecular Spectroscopy, 149, 771-789(2015).

15. Wang W., Guerro T., Merecias S.R., Garcia-Ortega H., Santillan R., Daran J.-D., Farfan N., Agustin D., Poli R., Substituent effects on solvent-free epoxidation catalyzed by dioxomolybdenum(VI) complex supported by ONO Schiff base ligands. Inorganica Chimica Acta, 431, 176-183(2015).

16. Aziz A.A.A., Salaem A.N.M., Sayed M.A., AboAly M.M., Synthesis, structural characterization, thermal studies, catalytic efficiency and antimicrobial activity of some M(II) complexes with ONO tridentate Schiff base N-salicylideneo-aminophenol $\left(\mathrm{saphH}_{2}\right)$. Journal of Molecular Structure. 1010, 130-138(2015).

17. Shabbir M., Akhter Z., Ahmad I., Ahmed S., Shafiq M., Mirza B., Mckee V., Munawar K.S., Ashraf A.R., Schiff base triphenylphoshine palladium(II) complexes: Synthesis, structural elucidation, electrochemical and biological evaluation. Journal of Molecular Structure. 1118, 250-258(2016).
18. Salehi M., Rahimifar F., Kubicki M., Asadi A., Structural, spectrocsopic, electrochemical and antibacterial studies of some new nickel(II) Schiff base complexes. Inorganica Chimica Acta, 443, 2835(2016).

19. Barauah J., Borah G., Kardong D., Ni(II), Cu(II) and $\mathrm{Pd}(\mathrm{II})$ Complexes of Anisaldehyde-4phenyl-thiosemicarbazone: synthesis, spectral characterization and biological study. Asian Journal of Chemistry 28(11), 2446-2452(2016).

20. Abo-Aly M.M., Salem A.M., Sayed M.A., Aziz A.A.A., Spectroscopic and structural studies of the Schiff base 3-methoxy-N-salicylidene-o-amino phenol complexes with some transition metal ions and their antibacterial, antifungal activities. Spectrochimica Acta Part A: Molecular and Biomolecular Spectroscopy, 136, 993-1000(2015).

21. Geeta B., Shravankumar K., Reddy P.M., Ravikrishna E., Sarangapani M., Reddy K.K., Ravinder V., Binuclear cobalt(II), nickel(II), copper(II) and palladium(II) complexes of a new Schiff-base as ligand: Synthesis, structural characterization, and antibacterial activity. Spectrochimica Acta Part A: Molecular and Biomolecular Spectroscopy, 77, 911-915(2010).

22. El-Saied F.A., Al-Hakimi A.N., Wahba M.A., Shakdofa M.M. E., Preparation, Characterization and Antimicrobial Activities of N'-((3(hydroxyimino) butan-2-ylidene)-2 (phenylamino) acetohydrazide and Its Metal Complexes. Egypt Journal of Chemistry, 60(1), 1-24(2017).

23. El-Saied F.A., Al-Hakimi A.N., Wahba M.A., Shakdofa M.M. E., Antibacterial Treatment of Cotton Fabrics using Methylisothiazolinone. Egypt Journal of Chemistry, 62(5), 15-27(2019).

24. Ikram M., Rehman S., Khan A., Baker R.J., Hofer T.S., Subhan F., Qayum M., Faridoon, Schulze C., Sythesis, characterization, antioxidant and selective xanthine oxidase inhibitory studies of transition metal complexes of novel amino acid bearing Schiff base ligand. Inorganica Chimica Acta, 428, 117-126(2015). 